\title{
Evaluation of Essential Metals and Arsenic in Poultry Feeds and Litters of Different Poultry Farms
}

\author{
Muhammad Waris*, Jameel Ahmed Baig, Tasneem Gul Kazi, Hassan Imran Afridi \\ National Centre of Excellence in Analytical Chemistry, University of Sindh, Jamshoro, Sindh, Pakistan \\ E-mail: warisarain90@gmail.com
}

Received: 26 September 2019; Accepted: 20 October 2019; Available online: 30 November 2019

\begin{abstract}
The current study was aim to evaluate the speciation of arsenic (total arsenic "TAs", arsenite “As"III" and arsenate "As" $\mathrm{V}$ ") and total contents of essential metals in the feeds and litters of branded poultry feed using farms (BPF) and non-branded poultry feed utilizing farms (NBPF) at Hyderabad Sindh, Pakistan. The TAs and essential metals determined by graphite furnace and flame atomic absorption spectrometry (GF and FAAS), respectively. Whereas, the $\mathrm{As}^{\mathrm{III}}$ and $\mathrm{As}^{\mathrm{V}}$ separated by solvent extraction followed by GF-AAS. The high levels of sodium, potassium, and zinc were observed in branded poultry feeds whilst calcium and iron contents were higher in non-branded poultry feed. The contents of total arsenic in poultry feed samples of both branded and non-branded poultry feed utilizing farms were within the NRC permissible limits (30.0 mg/kg) except NBPF-1 and NBPF-4. Total As in all poultry litter samples were found under the permitted monthly average dose of As (41.0 mg/kg) for agronomical application expert poultry litter samples of BPF-1, NPBF-2, and NPBF-3. The daily accumulation of total As from feed to boilers were also studied.
\end{abstract}

Keywords: Arsenic; Essential metals; Poultry feed; Poultry litter; Branded; Non-branded.

\section{Introduction}

Nowadays, the poultry forming is one of the most growing business in Pakistan due to increase in chicken meat consumer's demand [1]. However, broiler chicken provided about $60 \%$ of meat per annum to local consumers whilst rest of the chicken meat demand has been fulfilled by that layer and breeders who were at the end of egg production [1]. The poultry chickens are nourished by either locally formulated or commercial prepared feeds, which contain mixtures of plant-based products, zero size fishes, slaughterhouses animal waste, metallic and steel industrial by-products [2]. Moreover, the commonly non-dietary parts of chicken/broiler like viscera, heads, feet, and manure are added along with feather meal before autoclaving [3]. These sources of poultry production are excessively contaminated with toxic elements.

Among these toxic elements, the arsenic (As) is classified as a ubiquitous trace metalloid and the 52nd naturally abounding element in the earth's crust [4]. It is a powerful toxic element since the ancient times [5]. It has great application in the production of pharmaceuticals, poultry growth-promoters and agrochemicals (fungicides, herbicides, insecticides, wood preservatives, sheep-dips, and rodenticides) [6]. Meanwhile, several organic As containing drugs like arsenelic acid, carbasone, roxarsone, and nitrasone are used in the poultry industry as protozoan parasites disease controlled additives in the feed and faster growth of poultry birds [7]. It is reported that $>80 \%$ of total production of broiler chickens nourished by Roxarsone each year in the US [5]. The level of As in poultry feed was not properly monitored and managed due to their high cost. However, its transfer to human beings through the flesh of broilers has been evaluated [8]. The large quantity of As can be excreted in form of manure to contaminate the poultry litter $[8,9]$. These contaminated poultry litters used as fertilizers and causes the critical agronomical issue like the immobilization of $\mathrm{P}$ and $\mathrm{N}$ onto the soil and ultimately contaminated the groundwater with the high contents of $\mathrm{NO}_{3}$ and $\mathrm{PO}_{4}[5,10]$. The elevated contents of As and other trace and toxic elements in the poultry litter are the alarming condition [11]. The toxicological impact of As is extremely depending on its states or forms. The arsenite and arsenate may have several toxic effects [8]. Moreover, most of the intake roxarsone excreted in the unchanged form [9]. It is partly converted to $\mathrm{As}^{\mathrm{V}}$ whilst rest of the roxarsone is unidentified [5, 9, 12]. Thus, the As contaminated feeding to chickens may be released a huge amount of As into the environment from poultry litter $[3,8,13]$.

The accumulation and excretion of As and Zn in broilers from poultry feed has been studied [1, 8, 14]. But, the speciation of As in poultry feed and litter is need of the hour. Therefore, the aim and objectives of the current study are to assess the total and inorganic forms of As in poultry feed and litter. Moreover, the essential metals (sodium, potassium, calcium, and magnesium) in the samples of poultry feed and litter determined and assessed the 
correlation of the essential metals and As species in poultry feed with their levels in poultry litter. Arsenic (As) is most abundant trace metalloid [2, 4]. It has been reported that As is a foremost environmental toxicants due to its high biotoxicity, carcinogenicity, and phytotoxicity [3]. The contents of As were extremely increased than the maximum permissible limit for the total As $(10 \mu \mathrm{g} / \mathrm{L})$ in drinking water. This might be concerned to agricultural usage of As-containing poultry litter as fertilizer, which can ultimately contaminate the surface drinking water and could potentially be threaten to human/ ecological health [3, 5-8]. The possible contamination of As in poultry might be arisen from the intake of either contaminated poultry feed ingredients or the use of several organic As containing drugs (arsenelic acid, carbasone, roxarsone and nitrasone) as additive in the feed, to control protozoan parasites disease (coccidiosis) and to enhance weight gain and faster growth [5-8]. The excess amount of As in poultry feed and litter has been reported in different countries including Pakistan [5, 7-11]. Research to date strongly suggests that the toxicity of As is highly species dependent (Jackson et al. 2006). [5] The inorganic species (arsenite and arsenate) are believed to be most potent in inducing toxic effects [8, 12, 13].

The fluctuation in the levels of As along with essential metals was also reported in poultry feed and litters [1, $8,14,15]$. But, the speciation of As in poultry feed and litter was not well documented in the particular region. Thus, it is needed of an hour to quantify the levels of different As species in poultry feed and litter. To keep in view the above facts and figures, the current study was conducted to determine the total and inorganic species of As in poultry feed and litter. Meanwhile, the essential metals (calcium, iron, magnesium, potassium, sodium, and zinc) in poultry feed and litter samples were also investigated in view to evaluate their correlation with As species. The daily accumulation of total As in broilers were also studied.

\section{Experimental}

\subsection{Sample collection}

A survey has been conducted before sampling to sort out information regarding usage of type poultry feeds (branded or non-branded) in different poultry farms situated in the surrounding areas of Hyderabad, Sindh, Pakistan. Based on the usage of branded and non-branded poultry feed selected five poultry farms in each case. The poultry farm utilizing branded poultry feed termed as BPF and farm utilizing non-branded poultry feed abbreviated as NBPF. Five samples were randomly collected from each poultry farm. Simultaneously, fifty samples of litter were also sampled from same poultry farms during 2014-15 in duly labeled polyethylene zip bags, separately. The samples dried in a fuming hood system at room temperature and grounded by the electric grinder. The particle size of pulverized samples measured to be $100 \mathrm{~mm}$ by a nylon sieve. The samples stored in closed polyethylene bags.

\subsection{Instrumentational analysis}

The extractions were carried out by an ultrasonic bath Ultrasonic LC-30-H (Made in Germany). The arsenic contents were analyzed by atomic absorption spectrophotometer Hitachi (Tokyo, Japan) equipped with a graphite furnace GA-3 and essential metals analyzed by flame atomic absorption spectrometry (FAAS), deuterium lamp for background correction, Aspiration rate $(2 \mathrm{~mL} / \mathrm{min})$ and air as Oxidant $=1.6 \mathrm{~kg} / \mathrm{cm} 2$. The instrumental conditions for As and the essential metals as well as temperature programing for As listed in Table 1 and Table 2.

\subsection{Acid digestion method}

Total As, Ca, Fe, K, Mg, Na and Zn in CRM and poultry feed and litter samples were conducted by conventional acid digestion procedure reported elsewhere $[8,14]$.

\subsection{Sample preparation for $\mathrm{As}^{\mathrm{III}}$ and $\mathrm{As}^{\mathrm{V}}$}

For Separation of an inorganic fraction, weighed $0.2 \mathrm{~g}$ of six replicate subsample of CRM (DORM-2) and triplicate samples of each BPF, NBPF, and litter samples taken in the conical flasks. Then digested the samples by adding $5.0 \mathrm{ml} \mathrm{HClO}_{4}$ (concentrated) and $50 \mathrm{mg}$ of $\mathrm{Fe}_{2}\left(\mathrm{SO}_{4}\right)_{3}$ on a hot plate at $80{ }^{\circ} \mathrm{C}$ up to semi-dryness. The resulted digests diluted up to $10 \mathrm{ml}$ with $1.0 \mathrm{M} \mathrm{HCl}$. For the determination of As ${ }^{\mathrm{III}}, 5 \mathrm{ml}$ of each digested sample and $10 \mathrm{ml}$ of $1.0 \mathrm{M} \mathrm{HCl}$ taken in separating funnel and subjected to sonication in the ultrasonic bath for $5 \mathrm{~min}$. Then $5 \mathrm{ml}$ of chloroform added to each solution and sonicated twice for $1.0 \mathrm{~min}$ in the ultrasonic bath. The phase separation was done at room temperature. The resulted chloroform fraction poured into another separating funnel and extracted As ${ }^{\mathrm{III}}$ by $1.0 \mathrm{M} \mathrm{HCl}$.

For the determination of $\mathrm{As}^{\mathrm{V}}, 1 \mathrm{ml}$ of $\mathrm{HBr}$ and $15 \mathrm{mg}$ hydrazine sulfate added to the residual aqueous fractions for reduction of $\mathrm{As}^{\mathrm{V}}$ to $\mathrm{As}^{\mathrm{III}}$ and sonicated for $5 \mathrm{~min}$ at $80^{\circ} \mathrm{C}$ in an ultrasonic bath [16, 14]. After that these were treated with $5 \mathrm{ml}$ of chloroform in the ultrasonic bath for 1 min (twice). Then separated the $\mathrm{As}^{\mathrm{V}}$ from chloroform phase by using $10 \mathrm{ml}$ of $1.0 \mathrm{M} \mathrm{HCl}$. The all prepared samples were analyzed by ETAAS. 
Table 1. Measurement conditions for atomic absorption spectrometer (Hitachi 180-50 Japan)

\begin{tabular}{|c|c|c|c|c|c|}
\hline Elements & $\begin{array}{l}\text { Wave length } \\
(\mathrm{nm})\end{array}$ & $\begin{array}{l}\text { Slit width } \\
\text { (nm) }\end{array}$ & $\begin{array}{l}\text { Lamp current } \\
\text { (mA) }\end{array}$ & $\begin{array}{l}\text { Burner height } \\
(\mathrm{mm})\end{array}$ & $\begin{array}{l}\text { Fuel } \\
\left(\text { acetylene } \mathrm{kg} / \mathrm{cm}^{2} \text { ) }\right.\end{array}$ \\
\hline $\mathrm{Ca}$ & 422.7 & 2.6 & 7.5 & 12.5 & 0.40 \\
\hline $\mathrm{Fe}$ & 248.3 & 0.2 & 10 & 7.5 & 0.30 \\
\hline K & 766.5 & 2.6 & 10 & 7.5 & 0.30 \\
\hline $\mathrm{Mg}$ & 285.2 & 2.6 & 7.5 & 7.5 & 0.20 \\
\hline $\mathrm{Na}$ & 589.0 & 0.4 & 10 & 7.5 & 0.25 \\
\hline Zn & 213.8 & 1.3 & 7.5 & 7.5 & 0.20 \\
\hline
\end{tabular}

Table 2. Measurement conditions for graphite furnace atomic absorption spectrometry (GF-AAS) (Hitachi 18050 Japan)

\begin{tabular}{ll}
\hline Parameters & As \\
\hline Lamp Current $(\mathrm{mA})$ & 10 \\
Wave length $(\mathrm{nm})$ & 193.7 \\
Slit width (nm) & 2.6 \\
Cuvette & $\mathrm{Cup}$ \\
Dry & $80-120 / 15$ \\
Ash & $300-600 / 15$ \\
Atomization & $1500-1800 / 5$ \\
Cleaning & $1800-2000 / 2$ \\
Chemical modifier & $\left.\mathrm{Mg}\left(\mathrm{NO}_{3}\right)_{2}+\mathrm{Pd}_{(\mathrm{NO}}\right)_{2}$ \\
\hline
\end{tabular}

\subsection{Analytical Figure of Merit}

$0.2 \mathrm{~g}$ of each six replicate subsamples of branded poultry feed spiked with three known concentration of standards of both As species. The percentage recovery in each case were found to be quantitative as listed in Table 3 and Table 4. The percentage relative standard deviation (\%RSD) of six independent analyses of each sample confirmed the precision of the method with \%RSD $<2.0$. These results indicated the validation of a proposed method for the quantification both As species in poultry feed and litter samples. The obtained values of TAs in Dorm-2 were compared with certified value and literature reported values, respectively. The percentage recovery can be calculated as

$$
\% \text { Recovery }=\frac{\text { Found Values }}{\text { Certified or Literature Value }} \times 100
$$

The \% recovery of TAs in CRM (DORM-2) was found to be $>100$. It was estimated that texp value for TAs found to be $<t_{\text {crit }}(2.57)$ at $95 \%$ confidence level $(\alpha=0.05)$. The difference was not significant between found values and the certified / literature reported value ' $p>0.05$ (Table 3). The detection limit ofbeach arsenic species were calculated by $\mathrm{LOD}=3 \times(\mathrm{s} / \mathrm{m})$ and quantitation limits were calculated by $\mathrm{LOQ}=10 \times(\mathrm{s} / \mathrm{m})$, respectively. Where " $\mathrm{s}$ " is the standard deviation of 10 measurements of reagent blanks and " $\mathrm{m}$ " is the slope of the calibration curve. The LOD of As ${ }^{\mathrm{III}}$ were reached at 0.004 and $\mathrm{As}^{\mathrm{V}}$ at $0.005 \eta \mathrm{g} / \mathrm{g}$, while LOQ for $\mathrm{As}^{\mathrm{III}}$ and $\mathrm{As}{ }^{\mathrm{V}}$ were calculated as 0.011 and $0.017 \eta \mathrm{g} / \mathrm{g}$, respectively. The linear range of the calibration graph ranged from the quantification limit up to $50 \mathrm{\eta g} / \mathrm{g}$ for $\mathrm{As}^{\mathrm{III}}$ and $\mathrm{As} \mathrm{v}^{\mathrm{V}}$. The LODs of $\mathrm{Ca}, \mathrm{Fe}, \mathrm{Mg}, \mathrm{K}, \mathrm{Na}$ and $\mathrm{Zn}$ by flame atomic absorption spectrophotometer were 164, 69.2, 2.46, 14.0, 5.52 and $10.7 \eta \mathrm{g} / \mathrm{g}$, respectively.

Table 3. The resulted for tests of addition/recovery for $\mathrm{As}^{\mathrm{III}}$ and $\mathrm{As}^{\mathrm{V}}$ in branded poultry feed and litter

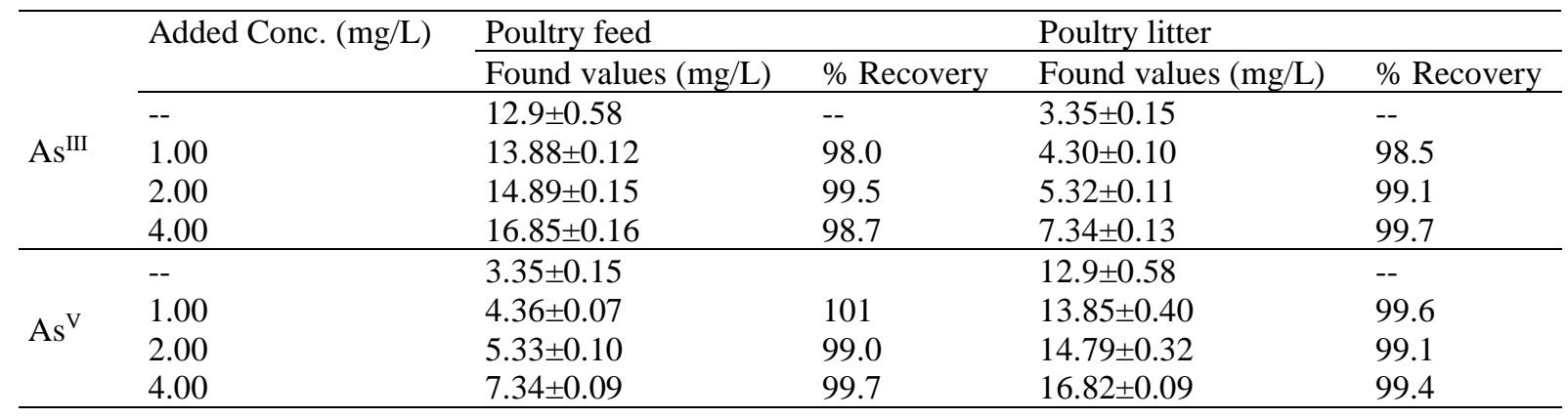


Table 4. Validation of total arsenic (mg/kg)

\begin{tabular}{lllll}
\hline CRM (DORM-2) & Certified Values & Found Values & $\%$ Recovery & $t_{\text {Experimental }}$ \\
\hline TAs & $18.0 \pm 1.10$ & $18.2 \pm 1.15$ & 101 & $2.52^{\mathrm{a}}$ \\
\hline $\begin{array}{l}\text { aPaired t-test between found values and certified/literature values, degree of freedom }(\mathrm{n}-1)=5, t_{\text {Critical }}=2.57 \text { at } 95 \% \text { confidence } \\
\text { level. }\end{array}$
\end{tabular}

\subsection{Estimation of daily accumulation in poultry bird}

For the current study, daily accumulation of essential metal and As in broiler from poultry feed has been estimated as:

$\mathrm{DA}=\mathrm{AFC} \times \mathrm{MC} / \mathrm{ACP}$

DA = Daily accumulation of essential metals and As from poultry feed (mg/day)

AFC = Average poultry feed consumption by each broiler $(4.2 \mathrm{~kg})$

$\mathrm{MC}=$ Mean Contents of metal in poultry feed $(\mathrm{mg} / \mathrm{kg})$

ACP = Average consumption period (84 days)

The required information for estimation of DA was collected during sampling from each poultry farm.

\section{Result and discussion}

\subsection{Essential metals and As species in poultry feed}

The essential metals ( $\mathrm{Na}, \mathrm{K}, \mathrm{Ca}, \mathrm{Mg}, \mathrm{Fe}$ and $\mathrm{Zn}$ ) concentrations in branded poultry feed samples of BPF-1, BPF-2, BPF-3, BPF-4 and BPF-5 were found in the ranged from (224-248, 1767-1877, 2090-2264, 410-454, 325359 and 2430-2580), (260- 297, 1098-1178, 2530-2714, 372-411, 257-292 and 2369-2541), (200-217, 581-625, 1973-2159, 320-354, 325-351 and 1200-1300), (281-303, 986-1078, 2866-3044, 396-437, 531-591 and 2554-2712) and (366-403, 408-460, 2759-2929, 450-498, 381-409 and 1246-1386) mg/kg, respectively. The contents of (Na, $\mathrm{K}$, Ca, Mg, Fe and Zn) in non-branded poultry feed samples of NBPF-1, NBPF-2, NBPF-3, NBPF-4, and NBPF5 were found in the concentration range from (290-320, 447-487, 7066-7578, 408-442, 831-901 and 2413-2563), (151-167, 481-521, 2346-2542, 320-348, 520-574 and 2048-2196), (241-261, 426-452, 10046-10710, 421-454, 711-755 and 2107-2247), (123-139, 859-921, 8224-8998, 280-299, 588-830 and 1914-2062) and (367-389, 455487, 10261-11049, 450-491, 589-657 and 1221-1323) mg/kg, respectively. Na and K levels were comparatively higher in branded than non-branded poultry feed. BPF-5 has the highest amount of Na than rest of branded feed samples of respected poultry farms. The levels of $\mathrm{Na}$ in farms of branded poultry feed can be expressed in decreasing order as BPF-5> BPF-4 > BPF-3 > BPF-2 > BPF-1. Whilst among farms of non-branded poultry feed, the NBPF-5 has the highest concentration of Na than the rest of farms of non-branded poultry feed. However, the levels of $\mathrm{Na}$ in non-branded and branded poultry feed samples were lower than the recommended maximum required nutrient requirement for $\mathrm{Na}(1200 \mathrm{mg} / \mathrm{kg}$ ) in the broiler (age 6-8 week) by NRC [17]. The K levels in branded poultry feed of different farms showed that the $\mathrm{K}$ contents were found in decreasing order as BPF-1> BPF-2> BPF-4> BPF-3 > BPF-5. Whilst the highest level of $\mathrm{K}$ was observed in non-branded poultry feed samples of NBPF-4. The contents of K in branded poultry feed and non-branded poultry feed samples of all studied poultry farms are lower than the recommended maximum nutrients requirement for $\mathrm{K}(3000 \mathrm{mg} / \mathrm{kg})$ in the broiler (age 68 week) by NRC [17].

The Ca levels in branded and non-branded poultry feed samples were comparatively higher than other studied essential metals ( $p>0.05$ ). The contents of $\mathrm{Ca}$ in studied branded and non-branded poultry feed samples of different farms were lower than the recommended maximum nutrients requirement for Ca $(8000 \mathrm{mg} / \mathrm{kg}) \mathrm{in}$ the broiler (age 6-8 week) by NRC expect NBPF-3, NBPF-4 and NBPF-5 [17]. The Concentration of Ca in BPF-4 is higher than the other branded feeds and order in decreasing trend expressed as BPF-4> BPF-5> BPF-2>BPF-1> BPF-3. The highest contents of Ca were observed in non-branded poultry feeds of poultry farm NBPF-5 whilst lower was obtained in NBPF-2. It is because of the addition of a high amount of supplementary minerals of Ca in the poultry feed. Calcium along with phosphorus is necessary for the formation and maintenance of the skeletal structure and for good egg-shell quality [18]. In case of non-branded poultry feed of respected poultry farms have the considerable high amount of Ca that might be due to the addition of limestone and fishmeal. These are added to feeds in order to strengthen bones have also enriched with Ca [19].

The Mg levels in branded and non-branded poultry feed samples were comparable. However, Mg contents in studied branded and non-branded poultry feed samples of different farms were lower than the recommended maximum nutrients requirement for $\mathrm{Mg}(600 \mathrm{mg} / \mathrm{kg}$ ) in the broiler (age 6-8 week) by NRC [17] The Concentration of $\mathrm{Mg}$ in BPF-5 is higher than the rest of branded feed samples of all poultry farms. The Mg in poultry feed of different farms are observed in decreasing trend as: BPF-5 > BPF-1 > BPF-4 > BPF-2 > BPF-3. The results of non-branded poultry feeds of different farms showed that the highest levels of Mg were observed in NBPF-5 whilst lower were in NBPF-4. Mg is supplemented in poultry feed in order to enhance hepatic catalase activity, decreases lipid and muscle tissue peroxidation and subsequently can improve meat quality [20, 21]. 
Trace elements including $\mathrm{Fe}$ and $\mathrm{Zn}$ are also important for poultry birds because these are a functional component of larger molecules and as co-factors of enzymes in various metabolic reactions. The resulted data showed that the Fe contents in non-branded poultry feed samples of different farms were found to be higher as compared to branded poultry feed samples of different farms. The levels of Fe in branded and non-branded poultry feed samples were the poultry farm BPF-4 has the highest concentration of Fe among branded poultry feed samples and contents of Fe in feed samples of different farms in increasing order as BPF-2 $<$ BPF- $1<$ BPF-3 $<$ BPF-5 $<$ BPS-4. Practical poultry diets should be supplemented with major and trace minerals because typical cereal-based diets are deficient in them as reported elsewhere [18]. The data of non-branded poultry feed samples showed that the poultry feed samples of NBPF-1 have the highest concentration of Fe whilst poultry feed samples of NBPF-2 have lowest contents (Table 5).

Table 5. The analytical results of essential metals and As species in poultry feed samples (dry mass basis) of different farms $(\mathrm{mg} / \mathrm{kg})$

\begin{tabular}{llllllllll}
\hline & $\mathrm{Na}$ & $\mathrm{K}$ & $\mathrm{Ca}$ & $\mathrm{Mg}$ & $\mathrm{Fe}$ & $\mathrm{Zn}$ & $\mathrm{TAs}$ & $\mathrm{As}^{\mathrm{III}}$ & $\mathrm{As}^{\mathrm{V}}$ \\
\hline BPF-1 & $236 \pm 11.8$ & $1822 \pm 54.7$ & $2177 \pm 87.1$ & $432 \pm 21.6$ & $342 \pm 17.1$ & $2505 \pm 75.2$ & $17.3 \pm 0.78$ & $3.35 \pm 0.15$ & $12.9 \pm 0.58$ \\
& $224-248$ & $1767-1877$ & $2090-2264$ & $410-454$ & $325-359$ & $2430-2580$ & $16.2-17.8$ & $2.57-4.13$ & $12.3-13.5$ \\
BPF-2 & $277 \pm 16.6$ & $1138 \pm 39.8$ & $2622 \pm 91.8$ & $391 \pm 19.6$ & $280 \pm 12.6$ & $2455 \pm 86.2$ & $30.2 \pm 1.51$ & $5.38 \pm 0.21$ & $10.1 \pm 0.51$ \\
& $260-297$ & $1098-1178$ & $2530-2714$ & $372-411$ & $257-292$ & $2369-2541$ & $28.7-31.7$ & $5.17-5.59$ & $9.59-10.6$ \\
BPF-3 & $209 \pm 8.37$ & $601 \pm 24.1$ & $2066 \pm 93.0$ & $337 \pm 16.9$ & $338 \pm 13.2$ & $1250 \pm 50.0$ & $10.3 \pm 0.53$ & $2.17 \pm 0.12$ & $7.55 \pm 0.42$ \\
& $200-217$ & $625-581$ & $1973-2159$ & $320-354$ & $325-351$ & $1200-1300$ & $9.77-10.8$ & $2.05-2.29$ & $7.13-7.97$ \\
BPF-4 & $293 \pm 10.3$ & $1032 \pm 46.5$ & $2955 \pm 88.7$ & $416 \pm 20.9$ & $561 \pm 29.8$ & $2633 \pm 79.0$ & $11.3 \pm 0.63$ & $3.35 \pm 0.20$ & $4.65 \pm 0.28$ \\
& $281-303$ & $986-1078$ & $2866-3044$ & $396-437$ & $531-591$ & $2554-2712$ & $10.7-11.9$ & $3.15-3.55$ & $4.37-4.93$ \\
BPF-5 & $385 \pm 18.5$ & $434 \pm 25.6$ & $2844 \pm 85.3$ & $474 \pm 23.7$ & $395 \pm 14.2$ & $1316 \pm 69.8$ & $21.3 \pm 0.75$ & $2.34 \pm 0.14$ & $10.1 \pm 0.69$ \\
& $366-403$ & $408-460$ & $2759-2929$ & $450-498$ & $381-409$ & $1246-1386$ & $20.6-22.1$ & $2.20-2.48$ & $9.41-10.8$ \\
NBPF-1 & $305 \pm 15.3$ & $467 \pm 19.6$ & $7322 \pm 256$ & $425 \pm 17.0$ & $866 \pm 34.7$ & $2488 \pm 74.7$ & $45 \pm 1.80$ & $12.6 \pm 0.51$ & $23.0 \pm 0.92$ \\
& $290-320$ & $447-487$ & $7066-7578$ & $408-442$ & $831-901$ & $2413-2563$ & $44.2-45.8$ & $12.1-13.1$ & $22.1-23.9$ \\
NBPF-2 & $159 \pm 8.00$ & $501 \pm 20.1$ & $2444 \pm 97.8$ & $334 \pm 14.0$ & $547 \pm 26.6$ & $2122 \pm 74.2$ & $14.0 \pm 0.60$ & $4.16 \pm 0.17$ & $7.74 \pm 0.34$ \\
& $151-167$ & $481-521$ & $2346-2542$ & $320-348$ & $520-574$ & $2048-2196$ & $13.4-14.6$ & $3.99-4.33$ & $7.40-8.08$ \\
NBPF-3 & $251 \pm 10.0$ & $439 \pm 13.2$ & $10378 \pm 332$ & $437 \pm 16.6$ & $733 \pm 22.0$ & $2177 \pm 69.7$ & $20.3 \pm 0.93$ & $6.49 \pm 0.26$ & $10.1 \pm 0.47$ \\
& $261-241$ & $426-452$ & $10046-10710$ & $421-454$ & $711-755$ & $2107-2247$ & $19.4-21.2$ & $6.23-6.75$ & $9.63-10.6$ \\
NBPF-4 & $132 \pm 9.25$ & $890 \pm 31.2$ & $8611 \pm 387$ & $289 \pm 10.1$ & $609 \pm 21.3$ & $1988 \pm 73.6$ & $45.2 \pm 2.26$ & $14.0 \pm 0.56$ & $22.1 \pm 1.11$ \\
& $123-139$ & $859-921$ & $8224-8998$ & $280-299$ & $588-830$ & $1914-2062$ & $42.9-47.5$ & $13.4-14.6$ & $21.0-23.2$ \\
NBPF-5 & $378 \pm 11.4$ & $471 \pm 16.0$ & $10655 \pm 394$ & $471 \pm 21.2$ & $623 \pm 34.3$ & $1272 \pm 50.9$ & $11.3 \pm 0.60$ & $3.52 \pm 0.14$ & $5.67 \pm 0.28$ \\
& $367-389$ & $455-487$ & $10261-11049$ & $450-491$ & $589-657$ & $1221-1323$ & $10.7-11.9$ & $3.38-3.66$ & $5.37-5.95$ \\
\hline
\end{tabular}

*For each case, Mean \pm SD is shown in the first line and Range is shown in the second line.

It was observed that the highest contents of $\mathrm{Zn}$ in branded poultry feed samples of BPF-4 as compare to branded poultry feed samples of other poultry farms. The Zn contents in branded poultry feed samples of different farms were obtained in decreasing order as NBPF-4 > NBPF-1 > NBPF-2 > NBPF-5 > NBPF-3. In case of non-branded poultry feed samples of five poultry farms, the highest $\mathrm{Zn}$ contents were observed in poultry feed samples of NBPF-1 whilst lowest in NBPF-5. The Zn is supplemented with poultry for growth, feather and skeletal development and reproduction [22]. The Zn levels in branded and non-branded poultry feed samples were higher than the recommended required nutrients levels of Zn in feed samples for broiler by NRC [17] The significantly higher $\mathrm{Zn}$ in the branded and non-branded poultry feed samples in different broiler poultry farms suggested that there would be more Zn application in both poultry feeds with intensive farming developing and consistent with those findings reported elsewhere [22].

Several types of As compounds are generally utilized in poultry feeding to improve the weight gain, feed efficiency and pigmentation [23]. The TAs contents in branded poultry feed of BPF-1, BPF-2, BPF-3, BPF-4, and BPF-5 were found as 16.2-17.8, 28.7-31.7, 9.77-10.8, 10.7-11.9 and 20.6-22.1 mg/kg, respectively. Whereas, TAs in NBPF-1, NBPF-2, NBPF-3, NBPF-4, and NBPF-5 was found in the range of 44.2-45.8, 13.4-14.6, 19.4-21.2, 42.9-47.5, and 10.7-11.9 mg/kg respectively. However, the levels of TAs in branded poultry feed samples were within the permissible limits (30.0 mg/kg) [17]. However, NBPF-1 and NBPF-4 have high TAs levels than the NRC permissible limits of As in poultry feeds [16]. The As ${ }^{I I I}$ was found in branded poultry feed samples with the range from 2.57-4.13, 5.17-5.59, 2.05-2.29, 3.15-3.55 and 2.20-2.48 mg/kg in BPF-1, BPF-2, BPF-3, BPF-4, and BPF-5, respectively. On the other hand, in non-branded poultry feed samples As ${ }^{\mathrm{III}}$ was found within the range from 12.1-13.1, 3.99-4.33, 6.23-6.75, 13.4-14.6 and 3.3-3.66 in NBPF-1, NBPF-2, NBPF-3, NBPF-4, and NBPF-5, respectively. Whereas, the contents of $\mathrm{As}^{\mathrm{V}}$ in branded poultry feed, BPF-1, BPF-2, BPF-3 BPF-4 and BPF-5 were observed in the range of 12.3-13.5, 9.59-10.6, 7.13-7.97, 4.37-4.93 and 9.41-10.8 mg/kg, respectively. The resulted data of non-branded poultry feed shows NBPF-1, NBPF-2, NBPF-3, NBPF-4 and NBPF-5 range from (22.1-23.9, 7.40-8.08, 9.63-10.6, 21.0-23.2 and 5.37-5.95) mg/kg, respectively. The sum of inorganic As ${ }^{\mathrm{III}}$ and $\mathrm{As}^{\mathrm{V}}$ in branded feed samples were found in the range of 51 to $99 \%$ of TAs whilst inorganic As in non-branded poultry feed samples 
were found in between 87 to $92 \%$ of TAs (Table 5). The variation in TAs and inorganic As species in branded and non-branded poultry feed of different poultry forms of Sindh may be due to the difference in food additives formulation and process. Measured values of $\mathrm{As}^{\mathrm{III}}$ and $\mathrm{As}^{\mathrm{V}}$ in branded poultry feed samples are relatively lower than non-branded poultry feed samples $(\mathrm{p}<0.01)$.

\subsection{Essential metals and As species in poultry litter}

The mean concentration of $\mathrm{Na}, \mathrm{K}, \mathrm{Ca}, \mathrm{Mg}$, Fe and $\mathrm{Zn}$ in litter samples of BPF-1, BPF-2, BPF-3, BPF-4 and BPF-5 were found (287, 250, 4722, 310, 1490 and 172), (353, 1178, 4026, 872, 1007 and 174), (357, 885, 4202, 861, 1478 and 159), (325, 1417, 4737, 835, 1654 and 157), (468, 1323, 4115, 773, 835 and 1654) and (468, 1323, 4115, 773, 1243 and 158) mg/kg, respectively. The contents of $\mathrm{Na}, \mathrm{K}, \mathrm{Ca}, \mathrm{Mg}, \mathrm{Fe}$ and $\mathrm{Zn}$ in litter samples of NBPF-1, NBPF-2, NBPF-3, NBPF-4 and NBPF-5 were found (420, 452, 14488, 223, 4904 and 1433), (390, 1227, 16955, 258, 3476 and 2538) (392, 789, 17444, 285, 2042 and 4072), (237, 205, 5244, 204, 8619 and 1183) and (314, 388, 9533, 294, 11066 and 1011) $\mathrm{mg} / \mathrm{kg}$, respectively (Table 6). The resulted data revealed that the levels of Na contents in litter samples of BPF-5, K, Ca and Fe in litter samples of BPF-4, Mg in litter samples of BPF-3 and $\mathrm{Zn}$ in BPF-2 were significantly high $(\mathrm{p}<0.05)$. These variations might be due to different factors including nature of bedding materials, geographic areas, non-systematic feeding process, weather condition etc [14, 24].

Table 6. The analytical results of essential metals $(\mathrm{mg} / \mathrm{kg})$ and As species $(\mathrm{mg} / \mathrm{kg})$ in poultry litter samples of different farms (dry mass basis)

\begin{tabular}{llllllllll}
\hline & $\mathrm{Na}$ & $\mathrm{K}$ & $\mathrm{Ca}$ & $\mathrm{Mg}$ & $\mathrm{Fe}$ & $\mathrm{Zn}$ & $\mathrm{TAs}$ & $\mathrm{As}^{\mathrm{III}}$ & $\mathrm{AS}^{\mathrm{V}}$ \\
\hline BPF-1 & $287 \pm 14.3$ & $250 \pm 12.5$ & $4722 \pm 160$ & $310 \pm 15.5$ & $1490 \pm 44.7$ & $172 \pm 6.90$ & $49.2 \pm 1.97$ & $8.36 \pm 0.33$ & $24.1 \pm 0.96$ \\
& $273-302$ & $235-266$ & $4562-4882$ & $294-326$ & $1445-1535$ & $165-179$ & $47.2-51.1$ & $8.03-8.69$ & $23.1-25.1$ \\
BPF-2 & $353 \pm 15.9$ & $1178 \pm 35.4$ & $4026 \pm 120$ & $872 \pm 26.2$ & $1007 \pm 31.2$ & $174 \pm 8.73$ & $25.3 \pm 1.26$ & $4.29 \pm 0.21$ & $12.4 \pm 0.62$ \\
& $338-374$ & $1143-1213$ & $3906-4146$ & $846-898$ & $976-1038$ & $166-183$ & $24.0-26.6$ & $4.08-4.50$ & $11.8-13.0$ \\
BPF-3 & $357 \pm 14.3$ & $885 \pm 31.0$ & $4204 \pm 130$ & $861 \pm 30.2$ & $1478 \pm 47.3$ & $159 \pm 9.59$ & $23.3 \pm 1.33$ & $3.96 \pm 0.23$ & $11.4 \pm 0.65$ \\
& $344-374$ & $854-916$ & $4074-4334$ & $832-891$ & $1431-1525$ & $149-169$ & $22-24.6$ & $3.73-4.19$ & $10.8-12.1$ \\
BPF-4 & $325 \pm 11.4$ & $1417 \pm 51.0$ & $4737 \pm 151$ & $835 \pm 31.8$ & $1654 \pm 54.6$ & $157 \pm 8.66$ & $26.3 \pm 1.10$ & $4.47 \pm 0.19$ & $12.9 \pm 0.54$ \\
& $317-336$ & $1366-1468$ & $4586-4888$ & $866-895$ & $1079-1599$ & $149-166$ & $25.2-27.4$ & $4.28-4.66$ & $12.6-13.4$ \\
BPF-5 & $468 \pm 14.1$ & $1323 \pm 54.3$ & $4115 \pm 135$ & $773 \pm 30.9$ & $1243 \pm 42.3$ & $158 \pm 7.11$ & $12.3 \pm 0.59$ & $1.32 \pm 0.06$ & $10.6 \pm 0.51$ \\
& $456-482$ & $1269-1377$ & $3980-4250$ & $742-804$ & $1201-1285$ & $152-165$ & $11.7-13.0$ & $1.26-1.38$ & $10.1-11.1$ \\
NBPF-1 & $420 \pm 16.8$ & $452 \pm 18.1$ & $14488 \pm 435$ & $223 \pm 8.95$ & $4904 \pm 196$ & $1433 \pm 57.3$ & $34.2 \pm 1.37$ & $3.08 \pm 0.12$ & $9.93 \pm 0.40$ \\
& $404-437$ & $435-470$ & $14053-14923$ & $214-232$ & $4708-5100$ & $1376-1490$ & $32.8-35.6$ & $2.96-3.20$ & $9.53-10.3$ \\
NBPF-2 & $390 \pm 17.6$ & $1227 \pm 55.3$ & $16955 \pm 509$ & $258 \pm 11.6$ & $3476 \pm 156$ & $2538 \pm 114$ & $54.1 \pm 2.44$ & $4.87 \pm 0.22$ & $15.7 \pm 0.71$ \\
& $374-407$ & $1172-1282$ & $16446-17464$ & $247-270$ & $3320-3632$ & $2424-2652$ & $51.7-56.5$ & $4.65-5.09$ & $15.0-16.4$ \\
NBPF-3 & $392 \pm 16.5$ & $789 \pm 33.2$ & $17444 \pm 558$ & $285 \pm 12.0$ & $2042 \pm 85.8$ & $4072 \pm 171$ & $43.2 \pm 1.81$ & $4.36 \pm 0.18$ & $12.9 \pm 0.54$ \\
& $409-476$ & $756-822$ & $16886-18002$ & $273-297$ & $1956-2128$ & $3901-4243$ & $41.4-45.0$ & $4.18-4.54$ & $12.4-13.4$ \\
NBPF-4 & $237 \pm 7.12$ & $205 \pm 6.17$ & $5244 \pm 184$ & $204 \pm 6.13$ & $8619 \pm 258$ & $1183 \pm 35.5$ & $19.3 \pm 0.58$ & $1.64 \pm 0.05$ & $5.50 \pm 0.16$ \\
& $231-244$ & $199-211$ & $5060-5428$ & $199-210$ & $8361-8877$ & $1147-1219$ & $18.7-19.9$ & $1.59-1.69$ & $5.34-5.66$ \\
NBPF-5 & $314 \pm 14.5$ & $388 \pm 17.9$ & $9533 \pm 381$ & $294 \pm 13.5$ & $11066 \pm 509$ & $1011 \pm 46.5$ & $39.2 \pm 1.80$ & $3.33 \pm 0.15$ & $11.2 \pm 0.51$ \\
& $301-328$ & $370-407$ & $9152-9914$ & $281-308$ & $10557-11575$ & $965-1057$ & $37.4-41.0$ & $3.18-3.48$ & $10.7-11.7$ \\
\hline
\end{tabular}

*For each case, Mean \pm SD is shown in the first line and Range is shown in the second line.

The mean concentration of TAs in poultry litter samples of BPF-1, BPF-2, BPF-3, BPF-4, and BPF-5 were found to be 49.2, 25.3, 23.3, 26.3 and $12.3 \mathrm{mg} / \mathrm{kg}$, respectively whilst litter samples of NBPF-1, NBPF-2, NBPF3, NBPF-4, and NBPF-5 were found as 34.2, 54.1, 43.2, 19.3 and $39.2 \mathrm{mg} / \mathrm{kg}$, respectively (Table 6). Total concentrations of As in all tested poultry litter samples were less than the permitted monthly average As concentration $41 \mathrm{mg} / \mathrm{kg}$ for land application expert poultry litter samples of BPF-1, NPBF-2, and NPBF-3. However, TAs in litter samples were comparable with the reported study [25]. The [26] indicated that considerable amounts of As in litter could potentially be taken up by plants or mobilized once applied to agricultural soils. However, recent studies showed that greater than $70.0 \%$ of As in exposed loads of litter can be dissolved by rainfall and potentially leach into water bodies and increased the considerable level of As in drinking water [27]. Moreover, the As contents in groundwater samples of all studied areas were higher than WHO permissible level $(0.01 \mathrm{mg} / \mathrm{L})$ that may have potential risk for the local population. [28-30]. The concentrations of TAs in tested in litter samples were higher than reported values in poultry litters [26]. Whilst find to be same as reported elsewhere [3, 31].

The sum of inorganic $\mathrm{As}^{\mathrm{III}}$ and $\mathrm{As}{ }^{\mathrm{V}}$ in poultry litter samples of farms using branded poultry feed were found in the range of 42 to $99 \%$ of TAs whilst poultry litter samples of farms using non-branded poultry feed were found in between 80 to $99 \%$ of TAs (Table 6). The organic form of As found to be high in farms using branded feed as compared to using non-branded feed $(\mathrm{p}<0.05)$. It is might be due to the use of organic As compound like roxarsone in branded poultry feeds as reported in other studied [10, 32-34]. Moreover, the other possible source of organic As might be the grains of comment crops, small see fishes and waste product of animal or broiler chicken [26]. 


\subsection{Correlation of essential metal and As species in poultry feed and litter}

The correlation study indicated that K, Ca and Zn levels in non branded poultry feed were significantly correlated their levels in excretory product poultry litter $(r>0.65 ; \mathrm{p}<0.01)$. The $\mathrm{K}$, Ca and $\mathrm{Zn}$ in poultry litter were largely a reflection of their concentrations in the poultry feeds consumed and the efficiency of feed conversion by the birds [23, 35]. The contents of TAs in poultry feed and litter samples of both non branded and branded poultry farms were significantly correlated $(r>0.90 ; p<0.001)$. Meanwhile, the Fe and $\mathrm{Zn}$ contents branded feed and their litter were significantly correlated $(r>0.65 ; p<0.01)$ (Table 7). It because ferric and zinc sulfate are added as a supplement in branded poultry feed [35].

Table 7. Regression analysis between essential metals and total arsenic in poultry feed and litter samples of BPF and NBPF

\begin{tabular}{lll}
\hline Elements & $\mathrm{BPF}$ & $\mathrm{NBPF}$ \\
\hline $\mathrm{Na}$ & $\mathrm{y}=0.7905 \mathrm{x}+136.64$ & $\mathrm{y}=0.6761 \mathrm{x}+206.49$ \\
& $\mathrm{R}^{2}=0.6204$ & $\mathrm{R}^{2}=0.6082$ \\
$\mathrm{~K}$ & $\mathrm{y}=0.6203 \mathrm{x}+841.74$ & $\mathrm{y}=0.8848 \mathrm{x}+428.99$ \\
& $\mathrm{R}^{2}=0.7962$ & $\mathrm{R}^{2}=0.946$ \\
$\mathrm{Ca}$ & $\mathrm{y}=0.7986 \mathrm{x}+2338.3$ & $\mathrm{y}=-1.1355 \mathrm{x}+21562$ \\
& $\mathrm{R}^{2}=0.8528$ & $\mathrm{R}^{2}=0.8919$ \\
$\mathrm{Mg}$ & $\mathrm{y}=5.936 \mathrm{x}-1894.5$ & $\mathrm{y}=1.8103 \mathrm{x}-66.528$ \\
& $\mathrm{R}^{2}=0.7728$ & $\mathrm{R}^{2}=0.8443$ \\
Fe & $\mathrm{y}=1.964 \mathrm{x}+621.17$ & $\mathrm{y}=29.228 \mathrm{x}-13742$ \\
& $\mathrm{R}^{2}=0.6999$ & $\mathrm{R}^{2}=0.9693$ \\
Zn & $\mathrm{y}=0.0095 \mathrm{x}+145.12$ & $\mathrm{y}=0.2905 \mathrm{x}+1522.7$ \\
& $\mathrm{R}^{2}=0.614$ & $\mathrm{R}^{2}=0.5052$ \\
\hline
\end{tabular}

\subsection{Daily accumulation of essential metals and As in broiler}

The daily accumulation of essential metals and As in broilers may also be important. The average consumption of poultry feed by each broiler is about $4.2 \mathrm{~kg}$ in 84 days. Thus, the average daily accumulation (DA) of essential metals and As in broiler through poultry feed (branded and non-branded basis) was calculated to assess the essential metals and As accumulation at different levels in different poultry farms (Table 8). Information about the consumption of branded and non-branded poultry feed by broilers on different poultry farms of Hyderabad Sindh, Pakistan has to be gathered by verbal questionnaire. The calculation of DA of each essential metal and As was done based on each individual poultry farm. It because of differences in poultry feed formulation and consumption pattern on each poultry farm. The daily load of essential metals and As from poultry feed to broiler may have a better index for the estimation of possible exposure. The DA expressed in milligrams (essential metals and As) per day (Table 8). However, there is no information about the provisional tolerable daily accumulation for essential metals and As from poultry feed.

The DA of Na, K, Ca, Mg, Fe and $\mathrm{Zn}$ in broilers of poultry farms using branded poultry feeds were found in a range of 13.7-24.1, 11.8-73.4, 195-244, 14.7-44.9, 48.8-80.0 and 7.45-8.45 mg/kg, respectively. The daily accumulation of $\mathrm{Na}, \mathrm{K}, \mathrm{Ca}, \mathrm{Mg}, \mathrm{Fe}$, and $\mathrm{Zn}$ in broilers of poultry farms using non-branded poultry feed were obtained in between 11.5-21.9, 9.95-64.1, 253-900, 9.95-15.4, 97.8-579 and 48.3-212 mg/kg, respectively. However, the highest DA of Na was found in broilers of BPF-5; Ca, K and Fe in broilers of BPF-4; Mg in broilers of BPF-2 and Zn in broilers of BPF-3. On the other hand, the highest DA of Na was observed in broilers of NBPF1; $\mathrm{K}$ in broilers of NPBF-2; Ca and Zn in broilers of NBPF-3 whilst Mg and Fe were highest in broilers of NBPF5. The DA of TAs in broiler samples of poultry farms using branded poultry feed were found in the range of 0.590 $2.56 \mathrm{mg} / \mathrm{kg}$ whilst DA of TAs in broiler samples of poultry farms using non branded poultry feed were found in between $0.940-2.83 \mathrm{mg} / \mathrm{kg}$, respectively. The DA pattern of TAs in the broiler of poultry farms utilizing branded poultry feed is BPF-1 > BPF-4 > BPF-2 > BPF-3 and > BPF-5 whilst in the broiler of poultry farms utilizing non branded poultry feed, the DA pattern of TAs is: NBPF-2 > NBPF-3 > NBPF-5 > NBPF-1 and > NBPF-4. The DA values for $\mathrm{As}^{\mathrm{V}}$ in broiler from poultry feeds were comparatively higher than the $\mathrm{As}^{\mathrm{III}}$ values, which indicate that the broiler may less effect by the toxic arsenic (As $\left.{ }^{\mathrm{III}}\right)$.

\section{Conclusions}

The current study was carried out to quantify the level of essential metals and arsenic spices in branded and non-branded poultry feed and litter as well as their correlation with essential metals in poultry feed and litter. It is concluded that the levels of essential metals especially Ca were introduced in poultry feed excessively through food supplements in branded feed and as mountain stone in non-branded feed for the fast growth of broiler or 
layers. The contents of inorganic arsenic were comparatively high in the non-branded feed $(\mathrm{P}<0.05)$. It is because in non-branded feed the local poultry feed owners added inorganic gradients of arsenic for viral disease control. But the branded feed manufacturing companies added organic arsenical ingredients for disease control. The same trend was observed in poultry litter. Moreover, the correlation study indicated that the total arsenic in poultry feed were strongly correlated with their contents in poultry litter ( $<<0.05)$, which indicated that the main source of As contamination in poultry litter is the poultry feed and the sawdust, which was used to dry floor from wet excretory material of broiler (manure).

Table 8. Analytical results of estimated daily accumulation (DA) in mg/day of essential metals and arsenic species by broilers through branded and non-branded poultry feed

\begin{tabular}{llllllllll}
\hline & $\mathrm{Na}$ & $\mathrm{K}$ & $\mathrm{Ca}$ & $\mathrm{Mg}$ & $\mathrm{Fe}$ & $\mathrm{Zn}$ & $\mathrm{TAs}$ & $\mathrm{As}^{\mathrm{III}}$ & $\mathrm{AS}^{\mathrm{V}}$ \\
\hline BPF-1 & $14.4 \pm 0.72$ & $12.5 \pm 0.63$ & $236 \pm 8.00$ & $15.5 \pm 0.77$ & $74.5 \pm 2.24$ & $8.60 \pm 0.35$ & $2.46 \pm 0.10$ & $0.42 \pm 0.02$ & $1.21 \pm 0.05$ \\
& $13.7-15.1$ & $11.8-13.3$ & $228-244$ & $14.7-16.3$ & $72.3-76.7$ & $8.25-8.95$ & $2.36-2.56$ & $0.41-0.43$ & $1.16-1.26$ \\
BPF-2 & $17.7 \pm 0.80$ & $58.9 \pm 1.77$ & $201 \pm 6.00$ & $43.6 \pm 1.31$ & $50.4 \pm 1.56$ & $8.70 \pm 0.44$ & $1.27 \pm 0.06$ & $0.21 \pm 0.01$ & $0.62 \pm 0.03$ \\
& $16.9-18.7$ & $57.2-60.7$ & $195-207$ & $42.3-44.9$ & $48.8-51.9$ & $8.30-9.15$ & $1.20-1.33$ & $0.21-0.22$ & $0.59-0.65$ \\
BPF-3 & $17.9 \pm 0.72$ & $44.3 \pm 1.55$ & $210 \pm 6.50$ & $43.1 \pm 1.51$ & $73.9 \pm 2.36$ & $159 \pm 0.48$ & $1.17 \pm 0.07$ & $0.20 \pm 0.02$ & $0.57 \pm 0.03$ \\
& $17.2-18.7$ & $42.7-45.8$ & $204-217$ & $41.6-44.6$ & $71.6-76.3$ & $7.45-8.45$ & $1.10-1.23$ & $0.18-0.22$ & $0.54-0.60$ \\
BPF-4 & $16.3 \pm 0.57$ & $70.9 \pm 2.55$ & $237 \pm 7.55$ & $41.8 \pm 1.59$ & $82.7 \pm 2.73$ & $7.85 \pm 8.66$ & $1.32 \pm 0.06$ & $0.22 \pm 0.01$ & $0.65 \pm 0.05$ \\
& $15.9-16.8$ & $68.3-73.4$ & $229-244$ & $43.3-44.8$ & $80.0-53.9$ & $7.45-8.30$ & $1.26-1.37$ & $0.21-0.23$ & $0.60-0.70$ \\
BPF-5 & $23.4 \pm 0.71$ & $66.2 \pm 2.72$ & $206 \pm 6.75$ & $38.7 \pm 1.54$ & $62.2 \pm 2.11$ & $7.90 \pm 0.36$ & $0.62 \pm 0.03$ & $0.07 \pm 0.003$ & $0.53 \pm 0.03$ \\
& $22.8-24.1$ & $63.5-68.9$ & $199-212$ & $37.1-40.2$ & $60.1-64.3$ & $7.60-8.25$ & $0.59-0.65$ & $0.063-0.069$ & $0.50-0.56$ \\
NBPF-1 & $21.0 \pm 0.84$ & $22.6 \pm 0.91$ & $724 \pm 21.8$ & $11.2 \pm 0.45$ & $245 \pm 9.80$ & $71.6 \pm 2.86$ & $1.71 \pm 0.07$ & $0.15 \pm 0.01$ & $0.49 \pm 0.02$ \\
& $20.2-21.9$ & $21.8-23.5$ & $703-746$ & $10.7-11.6$ & $235-255$ & $68.8-74.5$ & $1.64-1.78$ & $0.14-0.16$ & $0.47-0.51$ \\
NBPF-2 & $19.5 \pm 0.88$ & $61.4 \pm 2.77$ & $848 \pm 25.5$ & $12.9 \pm 0.58$ & $174 \pm 7.80$ & $127 \pm 5.70$ & $2.71 \pm 0.12$ & $0.24 \pm 0.01$ & $0.78 \pm 0.04$ \\
& $18.7-20.4$ & $58.6-64.1$ & $823-873$ & $12.4-13.5$ & $166-182$ & $121-133$ & $2.59-2.83$ & $0.23-0.25$ & $0.74-0.82$ \\
NBPF-3 & $19.6 \pm 0.83$ & $39.5 \pm 1.66$ & $872 \pm 27.8$ & $14.3 \pm 0.60$ & $102 \pm 4.29$ & $204 \pm 8.55$ & $2.16 \pm 0.09$ & $0.22 \pm 0.01$ & $0.65 \pm 0.03$ \\
& $20.5-23.8$ & $37.8-41.1$ & $844-900$ & $13.7-14.8$ & $97.8-106$ & $195-212$ & $2.07-2.25$ & $0.21-0.23$ & $0.62-0.68$ \\
NBPF-4 & $11.9 \pm 0.36$ & $10.3 \pm 0.31$ & $262 \pm 9.2$ & $10.2 \pm 0.31$ & $431 \pm 12.9$ & $59.2 \pm 1.78$ & $0.97 \pm 0.03$ & $0.08 \pm 0.003$ & $0.26 \pm 0.01$ \\
& $11.5-12.2$ & $9.95-10.6$ & $253-271$ & $9.95-10.5$ & $418-443$ & $57.4-61.0$ & $0.94-0.99$ & $0.077-0.084$ & $0.25-0.27$ \\
NBPF-5 & $15.7 \pm 0.73$ & $19.4 \pm 0.90$ & $477 \pm 19.1$ & $14.7 \pm 0.68$ & $553 \pm 25.5$ & $50.6 \pm 2.33$ & $1.96 \pm 0.09$ & $0.167 \pm 0.007$ & $0.56 \pm 0.03$ \\
& $16.4-15.1$ & $18.5-20.4$ & $458-496$ & $14.1-15.4$ & $528-579$ & $48.3-52.9$ & $1.87-2.05$ & $0.159-0.174$ & $0.53-0.59$ \\
\hline
\end{tabular}

* For each case, Mean \pm SD is shown in the first line and Range is shown in the second line.

\section{References}

[1] Rehman K, Andleeb S, Mahmood A, Bukhar SM, Naeem MM, Yousaf K.Translocation of zinc and nickel from poultry feed to broilers and their excretion through litters. Global Veterinaria. 2012;8(6):660-664.

[2] Jackson BP, Bertsch P, Cabrera M, Camberato J, Seaman J, Wood C. Trace element speciation in poultry litter. Journal of Environmental Quality. 2003;32(2):535-540.

[3] Arai Y, Lanzirotti A, Sutton S, Davis J, Sparks D. Arsenic speciation and reactivity in poultry litter. Environmental Science \& Technology. 2003;37(18):4083-4090.

[4] Hantson P, Haufroid V, Buchet JP, Mahieu P. Acute arsenic poisoning treated by Intravenous Dimercaptosuccinic Acid (DMSA) and combined extrarenal epuration techniques. Clinical Toxicology. 2003;41(1):1-6.

[5] Jackson B, Seaman J, Bertsch P. Fate of arsenic compounds in poultry litter upon land application. Chemosphere. 2006;65(11):2028-2034.

[6] Khan A, Sharaf R, Khan MZ, Saleemi MK, Mahmood F. Arsenic toxicity in broiler chicks and its alleviation with ascorbic acid: a toxico-patho-biochemical study. International Journal of Agriculture and Biology. 2013;15(6).

[7] Silbergeld EK, Nachman K. The environmental and public health risks associated with arsenical use in animal feeds. Annals of the New York Academy of Sciences. 2008;140(1):346-357.

[8] Shah AQ, Kazi TG, Arain MB, Jamali MK, Afridi HI, Jalbani N, Baig JA, Kandhro GA. Accumulation of arsenic in different fresh water fish species-potential contribution to high arsenic intakes. Food Chemistry. 2009;112(2):520-524.

[9] Garbarino J, Bednar A, Rutherford D, Beyer R, Wershaw R. Environmental fate of roxarsone in poultry litter. I. Degradation of roxarsone during composting. Environmental Science \& Technology. 2003;37(8):15091514.

[10] Rutherford D, Bednar A, Garbarino J, Needham R, Staver K, Wershaw R. Environmental fate of roxarsone in poultry litter. Part II. Mobility of arsenic in soils amended with poultry litter. Environmental Science \& Technology. 2003;37(8):1515-1520 
[11] Nachman KE, Graham JP, Price LB, Silbergeld EK. Arsenic: a roadblock to potential animal waste management solutions. Environmental Health Perspectives. 2005;113(9):1123-1124.

[12] Nachman K, Raber G, Francesconi K, Navas-Acien A, Love D. Arsenic species in poultry feather meal. Science of the Total Environment. 2012;417(15):183-188.

[13] Stolz JF, Perera E, Kilonzo B, Kail B, Crable B, Fisher E, Ranganathan M, Wormer L, Basu P. Biotransformation of 3-nitro-4-hydroxybenzene arsonic acid (roxarsone) and release of inorganic arsenic by Clostridium species. Environmental Science \& Technology. 2007;41(3):818-823.

[14] Shah AQ, Kazi TG, Baig JA, Arain MB, Afridi HI, Kandhro GA, Wadhwa SK, Kolachi NF. Determination of inorganic arsenic species $\left(\mathrm{As}^{3+}\right.$ and $\mathrm{As}^{5+}$ ) in muscle tissues of fish species by electrothermal atomic absorption spectrometry (ETAAS). Food Chemistry. 2010;119(2):840-844.

[15] Mahesar SA, Sherazi ST, Niaz A, Bhanger MI, Siraj uddin, Rauf A. Simultaneous assessment of zinc, cadmium, lead and copper in poultry feeds by differential pulse anodic stripping voltammetry. Food and Chemical Toxicology. 2010;48(8-9):2357-2360.

[16] Koreňovská M, Suhaj M. Application of GF-AAS methods for $\mathrm{As}^{3+}$ and $\mathrm{As}^{5+}$ determination in fish products. Chemical Papers. 2005;59(3):153-156.

[17] National Research Council. Nutrient requirements of poultry, ninth rev. ed. Washington, DC: National Academy Press; 1994.

[18] Ravindran V. Poultry feed availability and nutrition in developing countries. Poultry Development Review. 2013:60-63.

[19] Nicholson F, Chambers B, Williams J, Unwin R. Heavy metal contents of livestock feeds and animal manures in England and Wales. Bioresource Technology. 1999;70(1):23-31

[20] Guo Y, Zhang G, Yuan J, Nie W. Effects of source and level of magnesium and vitamin E on prevention of hepatic peroxidation and oxidative deterioration of broiler meat. Animal Feed Science and Technology. 2003;107(1-4):143-150.

[21] Liu Y, Guo Y, Wang Z, Nie W. Effects of source and level of magnesium on catalase activity and its gene expression in livers of broiler chickens. Archives of Animal Nutrition. 2007;61(4):292-300.

[22] Zhang F, Li Y, Yang M, Li W. Content of heavy metals in animal feeds and manures from farms of different scales in northeast China. International Journal of Environmental Research and Public Health. 2012;(8):26582668.

[23] Li YX, Chen TB. Concentrations of additive arsenic in Beijing pig feeds and the residues in pig manure. Resources, Conservation and Recycling. 2005;45(4):356-367.

[24] Mahmoud MA, Abdel-Mohsein HS. Health risk assessment of heavy metals for Egyptian population via consumption of poultry edibles. Advance Animal Veterinary Science. 2015;3(1):58-70.

[25] Han FX, Kingery WL, Selim HM, Gerard PD, Cox MS, Oldham JL. Arsenic solubility and distribution in poultry waste and long-term amended soil. Science of the Total Environment. 2004;320(1):51-61.

[26] D'Angelo E, Zeigler G, Beck EG, Grove J, Sikora F. Arsenic species in broiler (Gallus gallus domesticus) litter, soils, maize (Zea mays L.), and groundwater from litter-amended fields. Science of the Total Environment. 2012;438:286-292.

[27] Fitz WJ, Wenzel WW. Arsenic transformations in the soil-rhizosphere-plant system: fundamentals and potential application to phytoremediation. Journal of Biotechnology. 2002;99(3):259-278.

[28] Baig JA, Kazi TG, Arain MB, Shah AQ, Kandhro GA, Afridi HI, Khan S, Kolachi NF, Wadhwa SK. Inorganic arsenic speciation in groundwater samples using electrothermal atomic spectrometry following selective separation and cloud point extraction. Analytical Sciences. 2011;27(4):439.

[29] Baig JA, Kazi TG, Shah AQ, Afridi HI, Khan S, Kolachi NF, Kandhro GA, Wadhwa SK, Shah F. Evaluation of toxic risk assessment of arsenic in male subjects through drinking water in southern Sindh Pakistan. Biological Trace Element Research. 2011;143(2):772-786.

[30] Baig JA, Kazi TG, Shah AQ, Kandhro GA, Afridi HI, Arain MB, Jamali MK, Jalbani N. Speciation and evaluation of Arsenic in surface water and groundwater samples: A multivariate case study. Ecotoxicology and Environmental Safety. 2010;73(5):914-923.

[31] Ashjaei S, Miller WP, Cabrera ML, Hassan SM. Arsenic in soils and forages from poultry litter-amended pastures. International Journal of Environmental Research and Public Health. 2011;8(5):1534-1546.

[32] Anderson BK, Chamblee TN. The effect of dietary 3-nitro-4-hydroxyphenylarsonic acid (roxarsone) on the total arsenic level in broiler excreta and broiler litter. Journal of Applied Poultry Research. 2001;10(4):323328.

[33] Bednar AJ, Garbarino JR, Ferrer I, Rutherford DW, Wershaw RL, Ranville JF, Wildeman TR. Photodegradation of roxarsone in poultry litter leachates. Science of the Total Environment. 2003;302(13):237-245.

[34] Chapman HD, Johnson ZB. Use of antibiotics and roxarsone in broiler chickens in the USA: analysis for the years 1995 to 2000. Poultry Science. 2002;81(3):356-364. 
[35] Wang H, Dong Y, Yang Y, Toor GS, Zhang X. Changes in heavy metal contents in animal feeds and manures in an intensive animal production region of China. Journal of Environmental Sciences. 2013;25(12):24352442.

(C) 2019 by the author(s). This work is licensed under a Creative Commons Attribution 4.0 International License (http://creativecommons.org/licenses/by/4.0/). Authors retain copyright of their work, with first publication rights granted to Tech Reviews Ltd. 